\title{
Optimization of the effect of PGPR-based biofertlizer on wheat growth and yield
}

\begin{abstract}
Halophilic rhizobacteria with potential for alleviation of salt stress in combination with -their plant growth promotion activities would be very useful tools in sustainable agriculture. In the present work, new formulations of biofertilizers have been developed and optimized using Box Bhenken experimental design and response surface methodology. The PGP potential of two halotolerant bacteria Piscibacillus salipiscarius E5 and Halomonas sp. G11, previously isolated from two salt lakes in Tunisian desert (Chott El-Djerid and Sabkhet El-Melah, respectively), was firstly confirmed by their multiple in vitro PGP activities such as phosphate solubilization, nitrogen fixation, indole acetic acid, hydrogen cyanide, siderophore, osmolytes and exopolysaccharides productions. The two selected isolates could potentially act in synergy to support plant growth under salt stress (up to $200 \mathrm{mM} \mathrm{NaCl}$ ). These bacteria were further inoculated with salt-stressed Triticum turgidum durumin (Mahmoudi cv.). Results demonstrated increases in root elongation, root dry weight, shoot elongation and shoot dry weight of inoculated wheat seedlings when compared to uninoculated control plants. The pot culture experiments showed significant response of selected PGP halotolerant bacteria on growth and productivity of durum wheat up to 90 days. The fitted mathematical models allowed us to plot response surfaces as well as isoresponse curves and to determine optimal PGP inoculants under salt stress. Results of this study revealed that using of PGPB biofertilizers especially dual inoculation had significant effects on durum wheat growth and yields
\end{abstract}

Keywords: extremely halotolerant PGPB, salt-stressed durum wheat, co-inoculation, statistical optimization, response surface methodology
Volume 7 Issue 3 - 2018

Fatma Naili,' Mohamed Neifar,' Darine Elhidri,' Hanene Cherif,' Bilel Bejaoui,' Manel Aroua,' Zoubeir Bejaoui, ${ }^{2}$ Mejda Abassi, ${ }^{2}$ Khaled Mguiz, ${ }^{2}$ Habib Chouchane,' Hadda,' Ouzari, ${ }^{3}$ Ameur Cherif'

'University of Manouba, ISBST, BVBGR-LRI IES3I, Biotechpole of Sidi Thabet, Tunisia

2University of Carthage, INRGREF, Unit of

Agrosulvopastoralisme, Tunisia

3University of Tunis El Manar, FST, MBA- LR03ES03, Tunisia

Correspondence: Ameur Cherif, LR Biotechnology and Bio-Geo Resources Valorization (LRI IES3 I), Higher Institute for Biotechnology, University of Manouba Biotechpole of Sidi Thabet, 2020, Sidi Thabet, Ariana, Tunisia, Tel 70527882 Email cherif.ameur@gmail.com

Received: April 18, 2018 | Published: June II, 2018

\section{Introduction}

In their natural environments, plants are constantly subjected to a number of abiotic and biotic stresses that can affect their life and productivity. Saline soils represent about $15 \%$ in arid and semi-arid regions and approximately $40 \%$ in irrigated lands in the world. High soil salinity adversely affects its physical, chemical and microbiological properties. Also, salt stress results in a significant decrease in productivity of salt-sensitive crops. At present, around 100 countries are affected by salinity induced abiotic stress and this is one of the world's most serious problem in agriculture. ${ }^{1,2}$ In Tunisia, salinization, desertification and soil erosion are the most pressing ecological concerns affecting the degradation and loss of productive agricultural lands. About the half of the total irrigated areas are considered at high risk for salinization. ${ }^{3,4}$ Recently, many projects such as BIODESERT (http://www.biodesert.unimi.it/), MADFORWATER (http://www.madforwater.eu/fr/) and PhosAgro/UNESCO/ IUPAC Green Chemistry for Life (https://www.phosagro.com) were planned and elaborated with the intent of managing microbial resources in arid and saline lands for the development of a sustainable agriculture through improving productivity and quality of vegetable crops and their resistance against biotic and abiotic stresses. Large collections of extremophilic bacteria isolated from arid and saline regions of southern Tunisia were generated and some of them showed a potential to promote plant growth under stressfull conditions. ${ }^{5-9}$

Plant growth-promoting bacteria (PGPB) are freeliving bacteria which promote plant growth and health either directly or indirectly. Direct mechanisms include nitrogen fixation, phosphate solubilization, iron sequestration and phytohormones synthesis. ${ }^{5,6,10,11}$ Indirect mechanisms include (i) The pathogen suppression through the production of siderophores, antibiotics and extracellular hydrolytic enzymes,

(ii) The bioremediation of contaminated rhizospheric soil and

(iii) The abiotic stress tolerance in plants. Rhizobacteria with plant growth promotion ability coupled with tolerance to abiotic stresses such as high temperature, drought and salinity would be extremely useful strategy in sustainable agriculture. ${ }^{12}$

The identification and characterization of novel salt-tolerant PGPBs has a great interest to promote crop growth and yield in saline soil-based agriculture. ${ }^{1,13-15}$ Successful application of statistical optimization tools like response surface methodology (RSM) to enhance crop growth and yield has been reported. ${ }^{16,17}$ However, studies regarding optimization of bioinoculation process under stressfull conditions are still few in the scientific literature. The aim of the present study was to investigate the effects of two novel halophilic PGPB, Piscibacillus salipiscarius E5 and Halomonas sp. G11 on durum wheat growth in the presence and absence of salt stress. To the best of our knowledge, this is the first study to modeling and optimization of salt-stressed durum wheat inoculation with these two bacterial strains.

\section{Methods}

\section{Bacterial strains and their characterization}

Extremely halotolerant strains Halomonas sp. G11 and Piscibacillus salipiscarius E5 used in this study were isolated from Chott el Djerid and Sabkhet el Melah salt-lakes of Southern Tunisia, respectively ${ }^{7}$. The optimal growths were found at $\mathrm{pH} 8$ in nutrient medium supplemented with $10 \% \mathrm{w} / \mathrm{v} \mathrm{NaCl}$ concentration. 


\section{Bioassays for plant growth promoting by selected PGPB strains}

G11 and E5 strains were screened for their PGP activities such as $\mathrm{N}_{2}$-fixation, inorganic tricalcium phosphate solubilization, production of siderophore, indol acetic acid and ammonia as described by Jensen, ${ }^{18}$ Nautiyal, ${ }^{19}$ Alexander and Zuberer, ${ }^{20}$ Salkowaski's, ${ }^{21}$ Cappuccino and Sherman ${ }^{22}$ and Vijayabaskar et al. ${ }^{23}$ respectively. All these experiments were conducted at $30^{\circ} \mathrm{C}, \mathrm{pH} 8$ with addition of $10 \% \mathrm{NaCl}$.

To prepare bacterial inocula of desired population size $\left(10^{8} \mathrm{CFU}\right.$ $\mathrm{ml}^{-1}$ ), G11 and E5 strains were grown in nutrient broth medium supplemented with $10 \%(\mathrm{w} / \mathrm{v}) \mathrm{NaCl}$ and incubated at $30^{\circ} \mathrm{C}$ for $72 \mathrm{~h}$. The durum wheat, variety Mahmoudi, with and without bacterial inoculum, was tested for salt tolerance at germination, seedling emergence and early seedling growth in $\mathrm{NaCl}$ solutions of different osmotic potentials. Seedling growth was estimated by measuring fresh and dry weights of the different parts of seedlings after drying the samples for $48 \mathrm{~h}$ at $80^{\circ} \mathrm{C} .{ }^{12,24}$

\section{Experimental design and greenhouse conditions}

Three variables BBD combined to response surface methodology 25 was carried out to optimize wheat growth promotion by selected halophilic PGPB strains under salt stress pot-experiments. Four seeds were planted in each pot and three replicates were used for each BBD experiment. Each pot was irrigated daily via a drip irrigation system. The greenhouse was maintained at high humidity with a constant temperature of $30 \pm 2^{\circ} \mathrm{C}$.

The relationship between the wheat grain yield responses $\left(\mathrm{Y}_{1}\right.$ : ear length, $\mathrm{Y}_{2}$ : number of spikelets/ear, $\mathrm{Y}_{3}$ : number of grains/ear) and the three studied variables, namely salt stress $\left(\mathrm{X}_{1}\right)$, E5 inoculum size $\left(\mathrm{X}_{2}\right)$ and $\mathrm{G} 11$ inoculum size $\left(\mathrm{X}_{3}\right)$, was approximated by the following second order polynomial function:

$$
\mathrm{Y}=\mathrm{b}_{0}+\mathrm{b}_{1} \mathrm{X}_{1}+\mathrm{b}_{2} \mathrm{X}_{2}+\mathrm{b}_{3} \mathrm{X}_{3}+\mathrm{b}_{11} \mathrm{X}_{1}^{2} 1+\mathrm{b}_{22} \mathrm{X}_{2}^{2}+\mathrm{b}_{33} \mathrm{X}_{3}^{2}+\mathrm{b}_{12} \mathrm{X}_{1} \mathrm{X}_{2}
$$
$+\mathrm{b}_{13} \mathrm{X}_{1} \mathrm{X}_{3}+\mathrm{b}_{23} \mathrm{X}_{2} \mathrm{X}_{3}$;

Where: $Y$ represent the measured responses; $b_{0}, b_{j}, b_{j k}$ and $b_{i j}$ are the BBD model coefficients. Generation and treatment of BBD data were performed using the specialized experimental design software NemrodW. ${ }^{26}$

\section{Analysis results}

\section{Plant growth promoting potential under saline conditions}

P. salipiscarius E5 and Halomonas sp. G11, previously isolated from two Tunisian salt lakes, showed multiple plant growth promoting traits under saline condition $(10 \% \mathrm{NaCl})$ such as phosphate solubilization, nitrogen fixation, indole acetic acid, hydrogen cyanide, siderophore, osmolytes and exopolysaccharides productions (Figure $1)$.

These bacteria were further inoculated with Triticum turgidum durumin (mahmoudi cv.) under salt stress $(100 \mathrm{mM} \mathrm{NaCl})$. Results demonstrated increases in root elongation, root dry weight, shoot elongation and shoot dry weight of inoculated wheat plants when compared to uninoculated (control) ones. The two selected PGPB strains can potentially act in synergy to support durum wheat growth under salt stress (Figure 2).

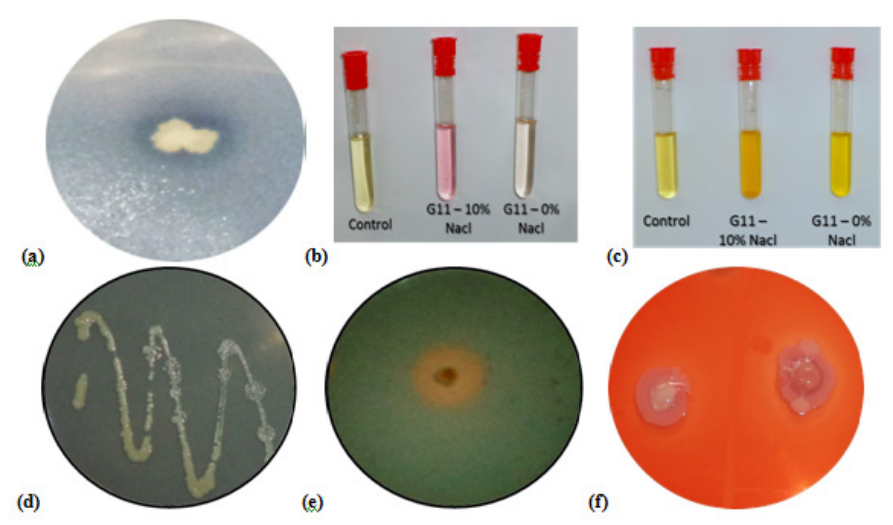

Figure I In-vitro plant growth promoting activities of the halophilic bacterium, Halomonas sp. GI I : (a) inorganic tri-calcium phosphate solubilization, (b) indol acetic acid production, (c) ammonia production ; and the halophilic bacterium Piscibacillus salipiscarius E5 : (d) nitrogen fixation, (e) siderophore production, (f) exopolysaccharide production.

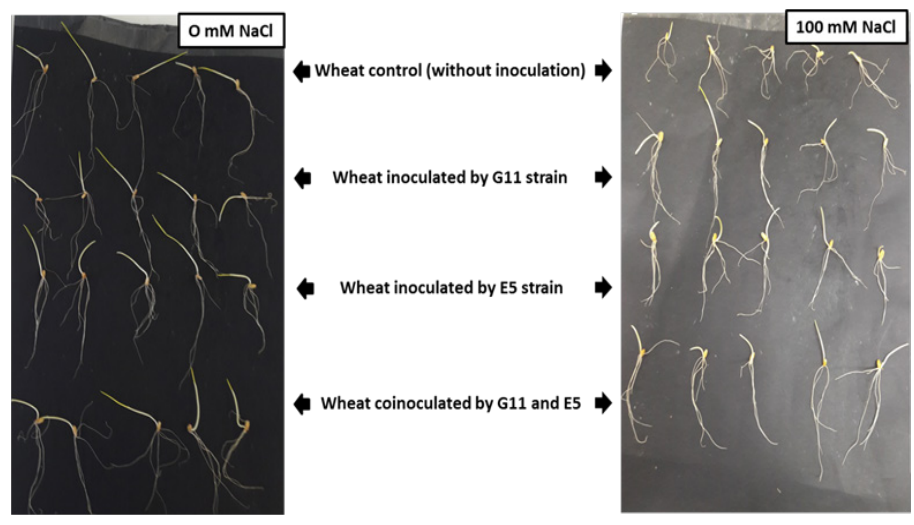

Figure 2 Root and shoot length of the plants in response to salt stress $(100 \mathrm{mM} \mathrm{NaCl})$ and inoculated with novel PGPB strains, Halomonas sp. GII and Piscibacillus salipiscarius E5.

\section{Statistical optimization of bacterial inoculant formula}

A BBD was carried out to evaluate the effects of wheat inoculation with $P$. salipiscarius E5 $\left(0-10^{8} \mathrm{CFU} / \mathrm{g}\right)$ and Halomonas sp. G11 $\left(0-10^{8} \mathrm{CFU} / \mathrm{g}\right)$ under salt stress $(0-200 \mathrm{mM})$ on the grain yields (Ear length, number of spikelets/ear and number of grains/ear). The BBD design matrix and the observed and predicted responses were given in Table 1. The model coefficients were determined using the last square method $^{25}$ and the predicted responses were calculated by NemrodW software. ${ }^{26}$

The following second order polynomial equations were modeled to determine the optimum requirement of E5 and G11 inoculant concentrations $\left(\mathrm{X}_{1}\right.$ and $\left.\mathrm{X}_{2}\right)$ and salt concentration $\left(\mathrm{X}_{3}\right)$ for maximum wheat yields:

$\mathrm{Y}_{1}$ : ear length $(\mathrm{cm})=2.750-0.328 \mathrm{X}_{1}+0.031 \mathrm{X}_{2}-0.109 \mathrm{X}_{3}+$ $0.719 \mathrm{X}_{1}^{2}+0.188 \mathrm{X}_{2}^{2}+0.156 \mathrm{X}_{3}^{2}+0.094 \mathrm{X}_{1} \mathrm{X}_{2}+0.063 \mathrm{X}_{1} \mathrm{X}-0.094$ $\mathrm{X}_{2} \mathrm{X}_{3}$ (Eq. 1)

$\mathrm{Y}_{2}$ : number of spikelets/ear $=5.938-0.781 \mathrm{X}_{1}-0.031 \mathrm{X}_{2}-0.250$ $\mathrm{X}_{3}+0.969 \mathrm{X}_{1}^{2}+0.219 \mathrm{X}_{2}^{2}-0.344 \mathrm{X}_{3}^{2}+0.125 \mathrm{X}_{1} \mathrm{X}_{2}+0.313 \mathrm{X}_{1} \mathrm{X}_{3}-$ $0.063 \mathrm{X}_{2} \mathrm{X}_{3}$ (Eq. 2) 
$\mathrm{Y}_{3}$ : number of grains/ear $=5.500-2.094 \mathrm{X}_{1}-0.031 \mathrm{X}_{2}-0.062 \mathrm{X}_{3}$ $+3.656 \mathrm{X}_{1}^{2}+1.656 \mathrm{X}_{2}^{2}-0.281 \mathrm{X}_{3}^{2}+0.688 \mathrm{X}_{1} \mathrm{X}_{2}+0.750 \mathrm{X}_{1} \mathrm{X}_{3}-0.375$ $\mathrm{X}_{2} \mathrm{X}_{3}$ (Eq. 3);

Where, $\mathrm{Y}_{1}, \mathrm{Y}_{2}$ and $\mathrm{Y}_{3}$ were predicted grain yield responses and $\mathrm{X}_{1}, \mathrm{X}_{2}$ and $\mathrm{X}_{3}$ were the coded values of $\mathrm{NaCl}$ concentration, $P$. salipiscarius E5 inoculum concentration and Halomonas sp. G11 inoculum concentration, respectively.

The statistical significance and the adequacy of the second- order model equations was checked using analysis of variance (ANOVA). ANOVA of the three developed regression models demonstrated high significance $(P<0.001)$ of the models and an insignificant lack of fit (Table 2), indicating that most of the variability in the responses could be explained by the second-order model equations.
The NemrodW software was used to produce three-dimensional (3D) response surface plots. The 3D surfaces are graphical representations of the regression equation for the optimization of wheat inoculation conditions in the studied experimental domain. In such plots, the response functions were presented as function of two factors while the third one was fixed at a constant level (Figure 3). The response plot revealed that an increase in salt concentration decreased the grain yields. However, the responses increased with the increase of inoculant size.

The optimum operating co-inoculation conditions of salt-stressed durum wheat, carried out numerically by using NemrodW software, were summarized in Table 3.

Figure 4 illustrated the positive effects of bacterial inoculation on the growth of the salt-stressed durum wheat plants.

Table I Experimental conditions of the BBD in coded and natural variables and the corresponding experimental and theoretical responses (predicted on the basis of second-order regression equations)

\begin{tabular}{|c|c|c|c|c|c|c|c|c|c|}
\hline $\begin{array}{l}\text { Experience } \\
\mathbf{N}^{\circ}\end{array}$ & $\begin{array}{l}\text { Salt } \\
\text { stress } \\
\text { (mM) }\end{array}$ & $\begin{array}{l}\text { E5 } \\
\text { inoculum } \\
\left(10^{8}\right. \\
\text { CFU/g) }\end{array}$ & $\begin{array}{l}\text { GII } \\
\text { inoculum } \\
\left(10^{8}\right. \\
\text { CFU/g) }\end{array}$ & $\begin{array}{l}\text { Experimental } \\
\text { ear length } \\
(\mathrm{cm})\end{array}$ & $\begin{array}{l}\text { Theoretical } \\
\text { ear length } \\
\text { (cm) }\end{array}$ & $\begin{array}{l}\text { Experimental } \\
\text { number of } \\
\text { spikelets/ear }\end{array}$ & $\begin{array}{l}\text { Theoretical } \\
\text { number of } \\
\text { spikelets/ } \\
\text { ear }\end{array}$ & $\begin{array}{l}\text { Theoretical } \\
\text { number of } \\
\text { spikeletsl } \\
\text { ear }\end{array}$ & $\begin{array}{l}\text { Theoretical } \\
\text { number of } \\
\text { grains/ear }\end{array}$ \\
\hline 1 & 0 & 0 & 0.5 & 4.25 & 4.047 & 8.5 & 8.063 & 14.5 & 13.625 \\
\hline 2 & 200 & 0 & 0.5 & 3.125 & 3.203 & 6.25 & 6.25 & 8 & 8.063 \\
\hline 3 & 0 & 1 & 0.5 & 4 & 3.922 & 7.75 & 7.75 & 12.25 & 12.188 \\
\hline 4 & 200 & I & 0.5 & 3.25 & 3.453 & 6 & 6.438 & 8.5 & 9.375 \\
\hline 5 & 0 & 0.5 & 0 & 3.875 & 4.125 & 7.5 & 7.906 & 10.75 & $|1.78|$ \\
\hline 6 & 200 & 0.5 & 0 & 3.375 & 3.344 & 5.75 & 5.719 & 6 & 6.094 \\
\hline 7 & 0 & 0.5 & 1 & 3.75 & 3.781 & 6.75 & 6.781 & 10.25 & 10.156 \\
\hline 8 & 200 & 0.5 & I & 3.5 & 3.25 & 6.25 & 5.844 & 8.5 & 7.469 \\
\hline 9 & 100 & 0 & 0 & 3.125 & 3.078 & 6 & 6.031 & 6.75 & 6.594 \\
\hline 10 & 100 & 1 & 0 & 3.5 & 3.328 & 6.5 & 6.094 & 8.25 & 7.281 \\
\hline 11 & 100 & 0 & I & 2.875 & 3.047 & 5.25 & 5.656 & 6.25 & 7.219 \\
\hline 12 & 100 & I & I & 2.875 & 2.922 & 5.5 & 5.469 & 6.25 & 6.406 \\
\hline 13 & 100 & 0.5 & 0.5 & 3 & 2.75 & 6.25 & 5.938 & 6 & 5.5 \\
\hline 14 & 100 & 0.5 & 0.5 & 2.5 & 2.75 & 5.75 & 5.938 & 5 & 5.5 \\
\hline 15 & 100 & 0.5 & 0.5 & 3 & 2.75 & 5.75 & 5.938 & 5 & 5.5 \\
\hline 16 & 100 & 0.5 & 0.5 & 2.5 & 2.75 & 6 & 5.938 & 6 & 5.5 \\
\hline
\end{tabular}

Table 2 ANOVA for the response surface quadratic BBD models

\begin{tabular}{llllll}
\hline Source of variation & Sum of squares & Degrees of freedom & Mean square & Ratio & Significance \\
\hline $\mathbf{Y}_{1}:$ ear length $\mathbf{( c m )}$ & & 9 & 11.6194 & $10.548 \mid$ & $* *$ \\
Regression & 104.5742 & 6 & 1.1016 & & \\
Residuals & 6.6094 & 3 & 1.8698 & 5.6094 & $9.6 \%(\mathrm{NS})$ \\
Validity & 5.6094 & 3 & 0.3333 & & \\
Error & $\mathrm{I}$ & 15 & & & \\
Total & $\mathrm{III.1836}$ & & & & \\
$\mathbf{Y}_{2}:$ number of spikelets/ear & 92.4319 & 9 & 10.2702 & 36.1283 & $* * *$ \\
Regression & & & & \\
\hline
\end{tabular}




\begin{tabular}{|c|c|c|c|c|c|}
\hline Source of variation & Sum of squares & Degrees of freedom & Mean square & Ratio & Significance \\
\hline Residuals & 1.7056 & 6 & 0.2843 & & \\
\hline Validity & $1.498 \mid$ & 3 & 0.4994 & 7.2199 & $7.0 \%$ (NS) \\
\hline Error & 0.2075 & 3 & 0.0692 & & \\
\hline Total & 94.1375 & 15 & & & \\
\hline \multicolumn{6}{|c|}{$Y_{3}:$ number of grains/ear } \\
\hline Regression & 244.3869 & 9 & 27.1541 & 21.0565 & $* *$ \\
\hline Residuals & 7.7375 & 6 & 1.2896 & & \\
\hline Validity & 1.6575 & 3 & 0.5525 & 0.2726 & $84.3 \%$ (NS) \\
\hline Error & 6.08 & 3 & 2.0267 & & \\
\hline Total & 252.1244 & 15 & & & \\
\hline
\end{tabular}

NS no significant **Significant at the level of $99.0 \% * * *$ Significant at the level of $99.9 \%$

Table 3 Optimal levels of halophilic bacterial inoculants leading to the highest grain yields of durum wheat when grown under salt stress

\begin{tabular}{|c|c|c|}
\hline Salt stress $\left(\mathbf{X}_{1}\right)$ & $\begin{array}{l}\text { Inoculum E5 }\left(\mathbf{X}_{2}\right)(\mathrm{CFU} / \mathrm{g}) \\
\text { Inoculum GII }\left(\mathbf{X}_{3}\right)(\mathrm{CFU} / \mathrm{g})\end{array}$ & Responses $\left(\mathbf{Y}_{1-2-3}\right)$ \\
\hline \multirow[t]{3}{*}{$50 \mathrm{mM}$} & $\mathrm{E} 5=0.910^{8}$ & ear length $Y_{1}=3.38 \mathrm{~cm}$ \\
\hline & $\mathrm{GII}=0.210^{8}$ & number of spikelets/ear $Y_{2}=6.76$ \\
\hline & & number of grains/ear $Y_{3}=8.55$ \\
\hline \multirow[t]{3}{*}{$100 \mathrm{mM}$} & $\mathrm{E} 5=1.010^{8}$ & ear length $Y_{1}=3.25 \mathrm{~cm}$ \\
\hline & $\mathrm{GII}=0.110^{8}$ & number of spikelets/ear $Y_{2}=6.14$ \\
\hline & & number of grains/ear $Y_{3}=7.27$ \\
\hline \multirow[t]{3}{*}{$200 \mathrm{mM}$} & $\mathrm{E} 5=1.010^{8}$ & ear length $Y_{1}=3.42 \mathrm{~cm}$ \\
\hline & $\mathrm{GII}=0.610^{8}$ & number of spikelets/ear $Y_{2}=6.40$ \\
\hline & & number of grains/ear $Y_{3}=9.37$ \\
\hline
\end{tabular}
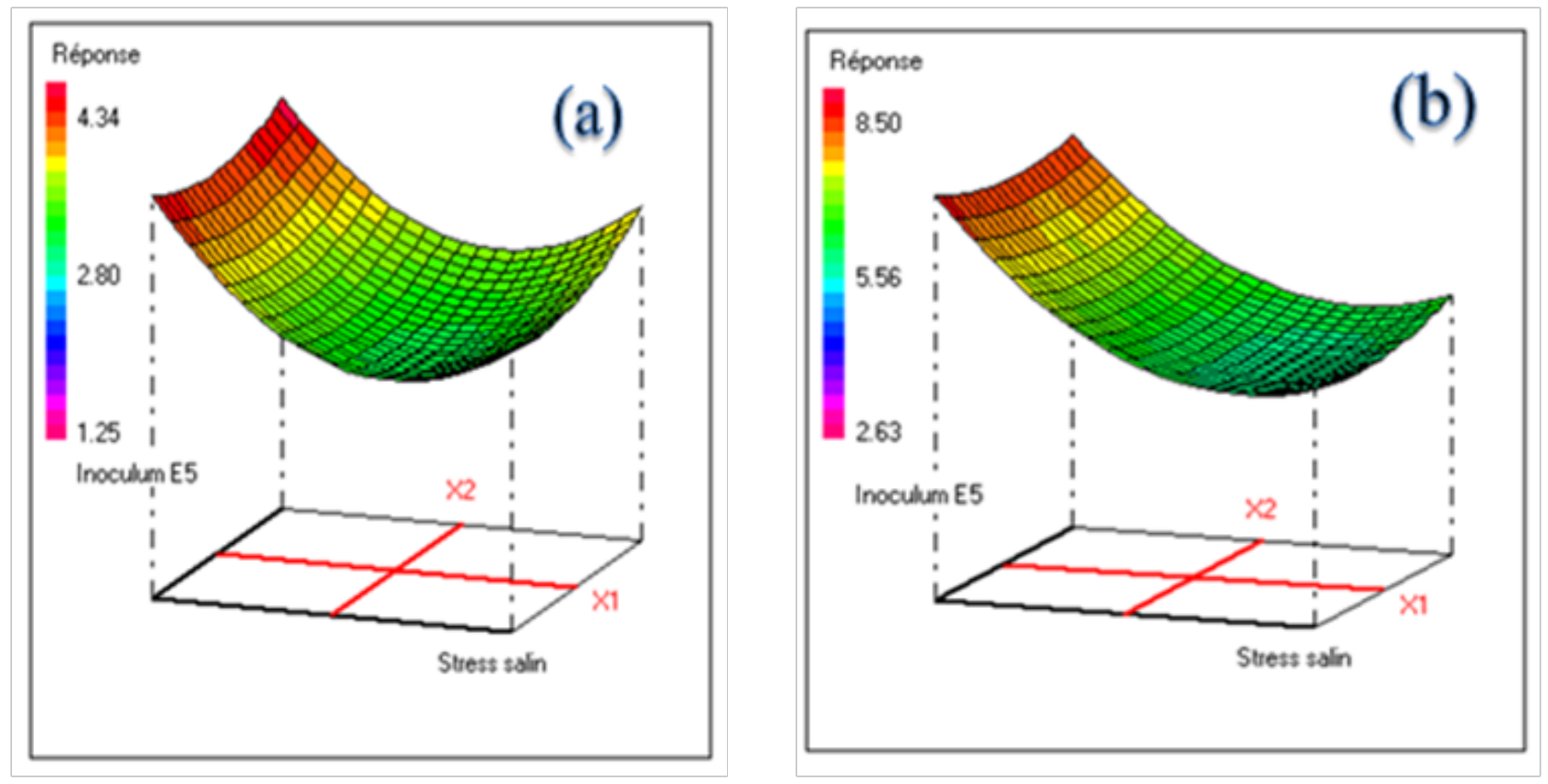


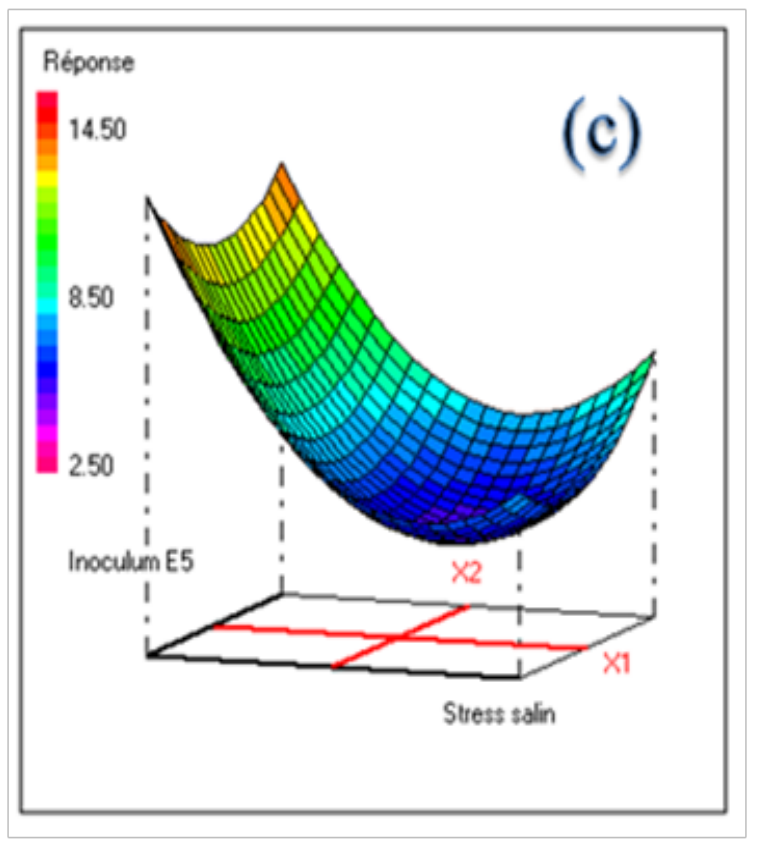

Figure 3 Contour response surface plots showing effect of salt stress and bacterial inoculum (Piscibacillus salipiscarius E5) on durum wheat grain yields: (a) $Y_{1}$ : ear length, (b) $Y_{2}$ : number of spikelets/ear and (c) $Y_{3}$ : number of grains/ear). The inoculum size of Halomonas sp. GII was fixed at $0.010^{8} \mathrm{CFU}$ per $\mathrm{g}$ of soil.

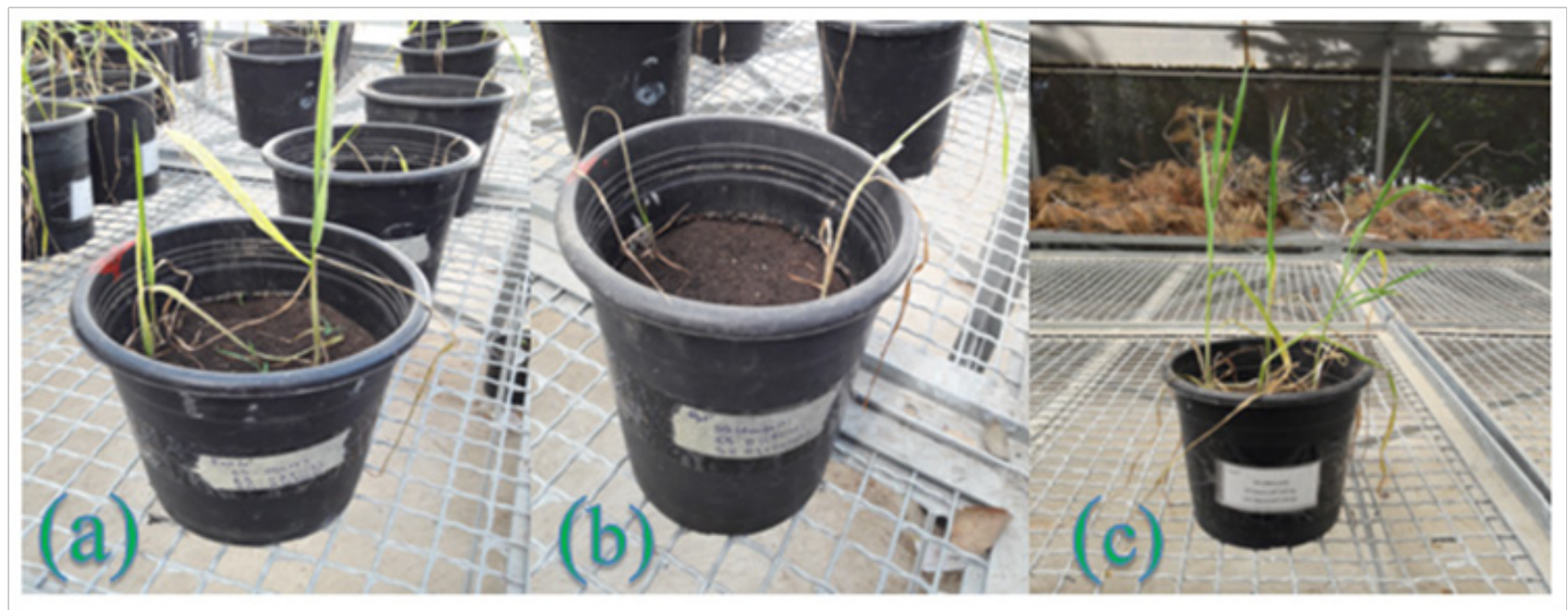

Figure 4 Representative pots of (a) non salt-stressed and non-inoculated, (b) salt-stressed (200 mM NaCl) and non-inoculated and (c) stressed (200 mM NaCl) and co-inoculated (I.0 $10^{8} \mathrm{CFU} / \mathrm{g}$ of PGPB E5 et $0.510^{8} \mathrm{CFU} / \mathrm{g}$ of PGPB GII) durum wheat cultivated under greenhouse conditions.

\section{Discussion and conclusion}

The goal of this study was to characterize the response of saltstressed durum wheat to the inoculation by the halophilic PGPB strains, Piscibacillus salipiscarius E5 and Halomonas sp. G11; and to determine if these PGPB could improve durum wheat salt-stress tolerance. In fact, the soluble salts when accumulated in the soil material leads to an increase in soil osmotic pressure, a decrease of plant water absorption and a nutritional imbalance in the plant rhizosphere. ${ }^{27}$ In the last decade, extensive research has been conducted to unravel the beneficial effects of halophilic PGPB on plant growth. ${ }^{27-31}$ Siddike et al. ${ }^{28}$ isolated 140 halotolerant bacterial strains from the soil of barren fields and the rhizosphere of halophytic plants in the vicinity of the
Yellow Sea, in the Republic of Korea, exhibiting nitrogen fixation, phosphorus and zinc solubilization, thiosulfate oxidation, production of indole acetic acid, ammonia and extracellular hydrolytic enzymes (protease, chitinase, pectinase, cellulase, and lipase). The inoculation of the halotolerant bacterial strains such as Brevibacterium epidermidis RS15, Micrococcus yunnanensis RS222, and Bacillus aryabhattai $\mathrm{RS} 341$ to enhance salt stress $(150 \mathrm{mM} \mathrm{NaCl})$ in canola plants produced a significant increase in root length and dry weight in comparison with the uninoculated positive controls. Mapelli et al. ${ }^{29}$ isolated 20 Halomonas strains from Sebkhet and Chott hypersaline ecosystems in Tunisia, having resistance to salinity and drought stresses and possessing PGP activities at $5 \% \mathrm{NaCl}$, such as nitrogen 
fixation, phosphate solubilisation, indol acetic acid and ammonia production. Furthermore, the PGPB Halomonas elongata revealed ability to massively adhere on Salicornia roots, investigating the suitability of halophilic PGPB to set up effective inocula. ${ }^{28}$ Dasele et al. ${ }^{30}$ described the plant growth promoting activities of Halobacillus sp. and Halomonas sp. including the production of indole acetic acid, hydrogen cyanide, ammonia, amylase and protease in presence of salinity $(21-29 \% \mathrm{NaCl})$ and heavy metals $(1 \mathrm{mM}$ cobalt, cadmium, and nickel and $0.04 \mathrm{mM}$ mercury and $0.03 \mathrm{mM}$ silver). Rajput et al. ${ }^{31}$ reported that the halophilic Planococcus rifietoensis strain, presented different plant growth promoting activities (indol acetic acid, phosphatases, ACC deaminase, etc.) that enhance the growth and yield of T. aestivum under salt stress. Similarly, the results of present study revealed that inoculation/co-inoculation with halophilic P. salipiscarius E5 and Halomonas sp. G11 had potential to improve the wheat growth. The plant growth promotion could be the result of the beneficial functions of applied PGPR isolates, like plant growth hormone production, nitrogen fixation, and $\mathrm{P}$ solubilization as reported in other studies. ${ }^{24,27-31}$ Moreover, E5 and G11 strains were able to decrease the significant inhibitory effect of salinity probably via the production of organic osmolytes.

The plant growth promotion effects of P. salipiscarius E5 and Halomonas sp. G11 on the salt-stressed durum wheat were evaluated and validated, experimentally using a BBD and RSM. Based on this experimental design, the durum wheat yields (Ear length, number of spikelets/ear and number of grains/ear) under each set of conditions were determined and compared with the corresponding predicted levels suggested by Nemrod W software. The obtained results suggested that the postulated models can be effectively used to predict the responses in the explored domain. The ANOVA indicated significant effects of salinity stress levels $(0-300 \mathrm{mM})$ and PGPB inoculants $\left(0-10^{8} \mathrm{CFU} / \mathrm{g}\right.$ of soil) on durum wheat yields. Generally, BBD data revealed that salt stress had a dramatic negative effect on the plant responses. The optimum doses of P. salipiscarius E5 and Halomonas sp. G11 for maximum durum wheat yields were found to be dependant to salt stress levels and plant growth stages. These results are consistent with previous reports evaluating the PGP potential of halophilic and halotolerant PGPB strains in salt affected soils. ${ }^{28-31}$

In conclusion, the use of halophilic PGPB in the agriculture can be considered as interesting and efficient strategy for enhancing crop growth under saline soil. In this study, our results showed that the two halophilic strains Piscibacillus salipiscarius E5 and Halomonas sp. G11, respectively isolated from Chott El-Djerid and Sabkhet ElMelah salt lakes in Tunisian desert, have the potential to improve durum wheat growth under salt stress due to their plant growth promoting properties such as nitrogen fixation, phosphate solubilization and production of stimulatory metabolites (exopolysaccharides, osmolytes, phytohormones, etc.). This study proved also that BoxBehnken experimental design and response surface methodology could be effectively used to modeling and optimizing the coinoculation of salt-stressed durum wheat by the two halophilic PGPB under pot house conditions, in order to enhance the wheat grain yields, including the ear length, the number of spikelets/ear and the number of grains/ear. The overall results suggest that inoculation/ co-inoculation with PGPB could be an effective approach to induce salinity tolerance and improve growth and yield of durum wheat under salt affected conditions compared to the uninoculated plants. Taking into account the search for more conservative and biological agricultural systems, crop inoculation with halophilic PGPB seems to be a promising tool leading to increased agricultural sustainability. Further microbial and physiological studies are required under field conditions and the mechanisms of osmoadaptation and plant growth promotion should be studied at molecular level.

\section{Acknowledgements \& funding details}

The authors acknowledge financial support from the PhosAgro/ UNESCO/IUPAC partnership in the ambit of the Green Chemistry for Life grant programme (project $\mathrm{N}^{\circ} 45003552865$ ) and the Tunisian Ministry of Higher Education and Scientific Research in the ambit of the laboratory project LR11ES31.

\section{Conflict of interest}

Authors declare that there is no conflict of interest.

\section{References}

1. Shin W, Siddikee MA, Joe MM, et al. Halotolerant Plant Growth Promoting Bacteria Mediated Salinity Stress Amelioration in Plants. Korean J Soil Sci Fert. 2016;49(4):355-367.

2. Etesami H, Beattie GA. Mining Halophytes for Plant Growth-Promoting Halotolerant Bacteria to Enhance the Salinity Tolerance of Nonhalophytic Crops. Front Microbiol. 2018;(9):148.

3. Sayar R, Bchini H, Mosbahi M, et al. Response of durum wheat (triticum durum Desf.) growth to salt and drought stresses. Czech J Genet Plant Breed. 2010;46(2):54-63.

4. Bouksila F. Sustainability of irrigated agriculture under salinity pressure-A study in semiarid Tunisia. Sweden: Media-Tryck, Lund; 2011

5. Hassen W, Neifar M, Cherif H, et al. Pseudomonas rhizophila S211, a New Plant Growth-Promoting Rhizobacterium with Potential in Pesticide-Bioremediation. Front Microbiol. 2018;(9):34.

6. Cherif H, Neifar M, Chouchane H, et al. Extremophile diversity and biotechnological potential from desert environments and saline systems of southern Tunisia. In: Extremophiles: From Biology to Biotechnology. USA: The CRC Press; 2018. p. 33-64.

7. El Hidri D, Guesmi A, Najjari A, et al. Cultivation-dependant assessment, diversity, and ecology of haloalkaliphilic bacteria in arid saline systems of southern Tunisia. Biomed Res Int. 2013;2013:1-15.

8. Guesmi A, Toumi B, El Hidri D, et al. Uneven distribution of Halobacillus trueperi species in arid natural saline systems of southern Tunisian sahara. Microb Ecol. 2013;66(4):831-839.

9. Ferjani R, Marasco R, Rolli E, et al. The date palm tree rhizosphere is a niche for plant growth promoting bacteria in the oasis ecosystem. Biomed Res Int. 2015;2015:153851.

10. Cherif H, Marasco R, Rolli E, et al. Oasis desert farming selects environment-specific date palm root endophytic communities and cultivable bacteria that promote resistance to drought. Env Microbiol Rep. 2015;(7):668-678.

11. Soussi A, Ferjani R, Marasco R, et al. Plant-associated microbiomes in arid lands: diversity, ecology and biotechnological potential. Plant Soil. 2016;(405):357-370

12. Pérez Montano F, Alías Villegas C, Bellogín RA, et al. Plant growth promotion in cereal and leguminous agricultural important plants: From microorganism capacities to crop production. Microbiol Res. $2014 ; 169: 325-336$ 
13. Torbaghan ME, Lakzian A, Astaraei AR. Salt and alkali stresses reduction in wheat by plant growth promoting haloalkaliphilic bacteria. $J$ Soil Sci Plant Nutr. 2017;17(4):1058-1073.

14. Shrivastava P, Kumar R. Soil salinity: A serious environmental issue and plant growth promoting bacteria as one of the tools for its alleviation. Saudi J Biol Sci. 2015;(22):123-131.

15. Upadhyay SK, Singh JS, Saxena AK, et al. Impact of PGPR inoculation on growth and antioxidant status of wheat under saline conditions. Plant Biol. 2012;(14):605-611.

16. Herrmann L, Lesueur D. Challenges of formulation and quality of biofertilizers for successful inoculation. App Microbiol Biotechnol. 2013;97(20):8859-8873.

17. Gundi JS, Santos MS, Oliveira ALM, et al. Development of liquid inoculants for strains of Rhizobium tropici group using response surface methodology. Afr J Biotechnol. 2018;17(13):411-421.

18. Jensen HL. Nitrogen fixation in leguminous plants. 1. General characters of root-nodule bacteria isolated from species of Medicago and Trifoliwn in Australia. Proc Linnean Soc NSW. 1942;(67):98-108.

19. Nautiyal CS. An efficient microbiological growth medium for screening phosphate solubilizing microorganisms. FEMS Microbial Lett. 1999;(170):265-270.

20. Alexander DB, Zuberer DA. Use of chrome azurol S reagents to evaluate siderophore production by rhizosphere bacteria. Biol. Fert Soil. $1991 ;(12): 39-45$.

21. Gordon SA, Weber RP. Colorimetric estimation of indoleacetic acid. Plant Physiol. 1951;(26):192-195.

22. Cappuccino JC, Sherman N. Microbiology: A Laboratory Manual. $3^{\text {rd }}$ Edn. New York: Benjamin/Cummings Pub. Co; 1992.
23. Vijayabaskar P, Babinastarlin S, Shankar T, et al. Quantification and characterization of exopolysaccharides from Bacillus subtilis (MTCC 121). Adv Biol Res. 2011;(5):71-76.

24. Abbasi MK, Yousra M. Synergistic effects of biofertilizer with organic and chemical $\mathrm{N}$ sources in improving soil nutrient status and increasing growth and yield of wheat grown under greenhouse conditions. Plant Biosyst. 2012;146:181-189.

25. Myers R, Montgomery DC, Anderson-Cook CM. Response Surface Methodology: Process and Product Optimization Using Designed Experiments. $3^{\text {rd }}$ edn. New York: Wiley; 2009.

26. Mathieu D, Nony J, Phan Tan Luu R. NEMROD-W Software. Marseille: LPRAI; 2000.

27. Orhan F. Alleviation of salt stress by halotolerant and halophilic plant growth-promoting bacteria in wheat (Triticum aestivum). Braz J Microbiol. 2016;47:621-627.

28. Siddikee MA, Chauhan PS, Anandham R, et al. Isolation, characterization, and use for plant growthpromotion under salt stress, of ACC deaminaseproducinghalotolerant bacteria derived from coastal soil. $J$ Microbiol Biotechnol. 2010;(20):1577-1584.

29. Mapelli F, Marasco R, Rolli E, et al. Potential for plant growthpromotion of Rhizobacteria associated with Salicornia growing in Tunisian hypersaline soils. BioMed Res Int. 2013.

30. Desale P, Patel B, Singh S, et al. Plant growth promoting properties of Halobacillus sp. And Halomonas sp. in presence of salinity and heavy metals. J Basic Microbiol. 2014;54:781-791.

31. Rajput L, Imran A, Mubeen F, et al. Salt-tolerant PGPR strain Planococcus rifietoensis promotes the growth and yield of wheat (Triticum aestivum) cultivated in saline soil. Pak J Bot. 2013;45:1955-1962. 